УДК 349.2

DOI https://doi.org/10.51989/NUL.2021.4.25

\title{
ІНДИВІДУАЛЬНИЙ ТРУДОВИЙ СПІР ЯК РІЗНОВИД САМОЗАХИСТУ ПРАЦІВНИКА У ТРУДОВИХ ВІДНОСИНАХ
}

\section{Тихонюк Ольга Володимирівна,} старший викладач кафедри господарського та адміністративного права Національного технічного університету України «Київський політехнічний інститут імені Ігоря Сікорського»

У статті акцентовано увагу на тому, що в Кодексі законів про працю України (КЗпП) наразі: 1) відсутнє визначення трудових відносин та притаманних їм ознак; 2) лише визначений порядок розгляду індивідуального трудового спору, але не роз'яснено, що ж це таке - індивідуальний трудовий спір; 3) не зрозуміло, що мається на увазі під самозахистом у трудових відносинах; 4) відсутня процедура медіації в трудових спорах.

Розглянуто строки у розгляді індивідуальних трудових спорів (які актуальні натепер і які пропонує законодавець). Наведено як причини виникнення індивідуальних трудових спорів, так і приклади поширених порушень прав працівників (щодо умов праці та їх оплати) з боку роботодавця. На підставі аналізу судової практики за останні 3 роки наведено типові (узагальнені) кейси з індивідуальних трудових спорів.

Зроблено такі висновки: 1) самозахистом у трудових відносинах, у нашому розумінні, вважається відмова від виконання роботи, яка не передбачена трудовим договором (ст. 31 КЗпП України), а також відмова від роботи, яка $\epsilon$ небезпечною для життя $і$ здоров'я працівника (4. 5 ст. 153 КЗпП України); або проведення переговорів з роботодавцем (самостійно чи за допомогою спеціально навченого фахівця, який володіє відповідними методиками з організації та ведення переговорів) щодо порушеного права з вимогою усунути це порушення; або звернення по допомогу до КТС або до суду; 2) «самозахистом від звільнення» вважаємо ситуацію, коли роботодавець хоче, але не може звільнити працівника (бо не отримав повної компенсації за завдані збитки), а працівник не хоче припиняти трудові відносини з роботодавцем, бо не впевнений, що зможе знайти собі іншу роботу; 3) допоки на законодавчому рівні не буде врегульовано медіацію, роботодавцю доцільно самостійно передбачити це на локальному рівні (наприклад, у колективному договорі) у трудових договорах із працівниками; 4) у разі прийняття проєкту Закону № 5054 трудовими відносинами вважатимуться відносини між працівником і роботодавцем, що передбачають виконання за дорученням, під керівництвом і контролем роботодавця особисто працівником за винагороду визначеної роботодавцем роботи; 5) у разі прийняття проєкту Закону № 5555 індивідуальним трудовим спором вважатимуться розбіжності між працівником і роботодавцем, що виникають після укладення трудового договору, до його укладення або після його припинення; 6) наразі судові рішення в малозначних справах (якими вважаються $і$ справи з трудових спорів) та у справах із ціною позову, що не перевищує 250 розмірів прожиткового мінімуму для працездатних осіб, не підлягають касаційному оскарженню (отже, сторона, яка програла справу, втрачає сенс на перегляд судового рішення суду першої та апеляційної інстанції касаційним судом, що у свою чергу порушує право особи на повноцінний судовий захист).

Ключові слова: трудові відносини, підпорядкованість, залежність, приховане працевлаштування, порушення прав працівника, самозахист, трудовий спір.

\section{Tykhonyuk Olga. Individual labor dispute as a type of self-protection of an employee in labor relations}

The article focuses on the fact that the Labor Code of Ukraine still: 1) lacks the definition of labor relations and their inherent characteristics; 2) only a certain procedure for consideration of an individual labor dispute, but does not explain what it is - an individual labor dispute; 3) it is not clear what is meant by self-protection in labor relations; 4) there is no mediation procedure in labor disputes.

The terms of consideration of individual labor disputes (relevant at the moment and offered by the legislator) are considered. Both the causes of individual labor disputes and examples of common violations of workers' rights (in terms of working conditions and their remuneration) 
by the employer are given. Based on the analysis of court practice for the last 3 years, typical (generalized) cases of individual labor disputes are given.

The following conclusions are made: 1) self-protection in labor relations, in our understanding, is the refusal to perform work not stipulated by the employment contract (Article 31 of the Labor Code of Ukraine), as well as the refusal to work, which is dangerous to life and health of the employee (Part 5 of Article 153 of the Labor Code of Ukraine); or negotiating with the employer (either independently or with the help of a specially trained specialist with the appropriate techniques for organizing and conducting negotiations) on the violated right with a demand to eliminate the violation; or seeking help from the Labor Dispute Commission or a court; 2) "self-defense against termination" is a situation where the employer wants to, but cannot, fire the employee (because he has not received full compensation for the damage caused), and the employee does not want to terminate his employment relationship with the employer because he is not sure that he will be able to find another job; 3) until mediation is regulated at the legislative level, it is advisable for the employer to independently anticipate at the local level (for example, in the collective agreement), in the employment contracts with employees; 4) in case of adoption of the Draft Law No. 5054, labor relations can be considered relations between the employee and the employer, providing for execution on behalf, under the guidance and control of the employer personally by the employee for remuneration of work determined by the employer; 5) in case of adoption of the Draft Law № 5555 an individual labor dispute will be considered as a disagreement between the employee and the employer, arising after the conclusion of the employment contract, before its conclusion or after its termination; 6) currently, court decisions in minor cases (which include cases on labor disputes) and in cases with a claim price not exceeding 250 minimum subsistence level for able-bodied persons are not subject to cassation appeal (hence, the losing party to the case, loses the sense to review the judgment of the court of first and appellate instance cassation court, which in turn violates the human right to a full judicial protection).

Key words: labour relations, subordination, dependence, hidden employment, violation of employee rights, self-defense, labour dispute.

Постановка проблеми. Як правило, будь-який трудовий спір - це непорозуміння (конфлікт) між працівником (або кандидатом у працівники чи вже колишнім співробітником) та роботодавцем щодо неспроможності вирішити проблему (або низку проблем), яка виникла (сторони або не чують одна одну, або не дочувають, або взагалі не виявляють бажання бути почутими) з приводу відносин праці. Наразі такі спори з поновлення порушених прав вирішуються в судовому та позасудовому порядку відповідно до глави XV чинного Кодексу законів про працю України (далі - КЗпП України). Але через те, що у КЗпП України наразі: 1) відсутнє визначення трудових відносин та притаманних їм ознак; 2) законодавець лише визначив порядок розгляду індивідуального трудового спору і при цьому не пояснив, що ж це таке - індивідуальний трудовий спір; 3) взагалі не зрозуміло, що мається на увазі під самозахистом у трудових відносинах; 4) відсутня процедура медіації в трудових спорах - на практиці все це створює певні незручності щодо правильного розуміння ситуації.
Метою статті $\epsilon$ спроба проаналізувати індивідуальний трудовий спір з точки зору самозахисту працівника в трудових відносинах, адже «кожен має право будь-якими не забороненими законом засобами захищати свої права і свободи від порушень і протиправних посягань» [1, 4. 6 ст. 55], навіть і в умовах певного дискомфорту з подачі законодавця.

Аналіз останніх досліджень і публікацій. Наразі індивідуальним трудовим спором прийнято вважати «належним чином умотивований (оформлений) трудовий спір між працівником і роботодавцем з приводу захисту порушеного трудового права», що «переданий на розгляд уповноваженого юрисдикційного органу в порядку, передбаченому законом» [2, с. 560]. Тобто перш ніж пред'являти претензії один одному (в судовому чи позасудовому порядку), сторони повинні перебувати в трудових відносинах між собою. У свою чергу, на думку науковців, під трудовими відносинами слід розуміти «суспільні відносини, які виникають у зв'язку з використанням фізичною особою здатності до праці шляхом реалізації 
права на працю та оформляються укладенням трудового договору з певним роботодавцем» $[2$, с. 560]. Отже, укладений трудовий договір $€$ запорукою існування трудових відносин. Звертаємо увагу, що чинний КЗпП України хоча і зазначає, що «Кодекс <...> регулює трудові відносини всіх працівників <...>» [3, 4. 1 ст. 1], але не пояснює, що слід розуміти під трудовими відносинами та які ознаки вони мають, хто $€$ сторонами трудових відносин та на підставі чого вони - трудові відносини - виникають; натомість у ч. 1 ст. 21 формально визнає їх наявність, адже на підставі укладеного трудового договору працівник зобов'язується виконувати роботу, а роботодавець зобов'язується виплачувати заробітну плату, створити належні й безпечні умови праці, необхідні для виконання роботи. Таким чином, індивідуальні трудові спори можливі виключно на підставі наявності трудових відносин або відносин, що виникають із трудових (також індивідуальний трудовий спір може виникати за наявності відносин, що передують трудовим, а саме в разі необґрунтованої відмови у працевлаштуванні).

Виклад основного матеріалу. Міжнародна організація праці у своїх Рекомендаціях про трудове правовідношення № 198 від 31.05.2006 р. зобов'язує держав-членів передбачити у своєму національному законодавстві конкретні ознаки існування трудового правовідношення, а саме:

1) «підпорядкованість» (тут і далі курсив наш - O.T.): робота виконується згідно з вказівками і під контролем іншої сторони; має місце інтеграція працівника в організаційну структуру підприємства; робота виконується виключно або переважно в інтересах іншої особи; виконується особисто працівником; виконується відповідно до певного графіку або на робочому місці, що зазначається або узгоджується стороною, яка замовила ії; має певну тривалість і припускає певну наступність (продовжуваність); вимагає особистої присутності працівника; передбачає надання інструментів, матеріалів і механізмів стороною, яка замовила роботу;

2) «залежність»: періодична виплата винагороди працівнику; дана винагорода $\epsilon$ єдиним або основним джерелом дохо- дів працівника; здійснення оплати праці в натуральному вигляді (харчові продукти, житло, транспортні засоби); визнання таких прав, як щотижневі вихідні дні й щорічні відпустки; оплата стороною, яка замовила проведення робіт, поїздок, що здійснюються працівником задля виконання роботи; відсутність фінансового ризику у працівника [4, п. 13].

Також у зазначених Рекомендаціях № 198 акцентується увага на тому, що критерії, якими визначається реальне існування трудових відносин, можуть змінюватися, незважаючи на те, що в багатьох країнах застосовуються такі загальні для всіх поняття, як «залежність» і «підпорядкованість». Тобто в нашому розумінні йдеться про так зване «осучаснення моделі трудових відносин» у вигляді прихованого працевлаштування шляхом підміни цивільно-правових відносин трудовими завдяки короткостроковим угодам, неформальним домовленостям та платі за конкретні виконані завдання, що начебто «дозволяє людям самостійно формувати свій графік та керувати прибутком, а компаніям - розвивати бізнес на найбільш вигідних для себе умовах <...>» [5].

Минуло 15 років з часу прийняття цих Рекомендацій № 198 і 08.02.2021р. на своєму позачерговому засіданні Кабінет Міністрів України схвалив проєкт Закону № 5054 «Про внесення змін до Кодексу законів про працю України щодо визначення поняття трудових відносин та ознак ïx наявності» [6] ${ }^{1}$, в якому визначено

\footnotetext{
$\overline{1}$ Зауважимо, що в разі ухвалення Верховною Радою України даного законопроєкту за наявності хоча би трьох будь-яких ознак із семи роботодавець буде зобов'язаний укласти з працівником трудовий договір, а працівник має бути забезпечений необхідним соціальним пакетом (відпустки, лікарняні, гарантії щодо збереження місця роботи); трудовими відносинами вважатимуться відносини між працівником і роботодавцем, що передбачають виконання за дорученням, під керівництвом і контролем роботодавця особисто працівником за винагороду визначеної роботодавцем роботи. На відміну від чинного КЗпП України проєкт Закону № 5054 пояснює, хто ж такі «працівник» і «роботодавець». Отже, працівник - це фізична особа, яка безпосередньо власною працею виконує оплачувану роботу в інтеpecax (на користь) іншої особи (роботодавця), а роботодавець - юридична чи фізична особа, яка використовує найману працю, на яку поширюється юрисдикція України чи іноземної держави, а також зареєстроване в Україні представництво іноземної юридичної особи (наразі відповідь на питання, хто такі «працівник» і «роботодавець» можна знайти,
} 
7 ознак наявності трудових відносин, а саме: 1) виконання особою роботи за конкретною кваліфікацією, професією, посадою за дорученням та під контролем особи, в інтересах якої виконуються роботи; 2) здійснення регулювання процесу праці, що має постійний характер та не передбачає встановлення особі конкретного визначеного результату (обсягу) робіт за певний період; 3) виконання роботи на робочому місці, визначеному або погодженому з особою, в інтересах якої виконуються роботи, з дотриманням установлених нею правил внутрішнього трудового розпорядку; 4) організація умов праці, зокрема надання обладнання, інструментів, матеріалів, сировини, робочого місця особою, в інтересах якої виконуються роботи; 5) систематична виплата винагороди особі, яка виконує роботу, в грошовій та/або в натуральній формі; 6) встановлення особою, в інтересах якої виконуються роботи, тривалості робочого часу та часу відпочинку; 7) відшкодування поїздок та інших фінансових витрат, пов'язаних із виконанням роботи особою, в інтересах якої виконується робота.

Трохи згодом у Верховній Раді України реєструється альтернативний законопроєкт № 5054-1 [7], яким пропонується обов'язкове укладання трудового договору з працівником за наявності будь-яких чотирьох ознак трудових відносин із семи (зауважимо, що ознаки, запропоновані розробниками проєктів Законів № 5054 і № 5054-1, такі ж самі, як і в Рекомендаціях МОП № 198)².

наприклад, у Законі України «Про порядок вирішення колективних трудових спорів (конфліктів)» від 03.03.1998 р.: найманий працівник - фізична особа, яка працює за трудовим договором на підприємстві, в установі та організації, в їх об'єднаннях або у фізичних осіб, які використовують найману працю (ч. 2 ст. 1), а роботодавець - це юридична (підприємство, установа, організація) або фізична особа, яка в межах трудових відносин використовує працю фізичних осіб (ч. 3 ст. 1)).

${ }^{2}$ Слід зазначити, що напередодні реєстрації законопроєктів № 5054 і № 5054-1 у Верховній Раді України, 02.02.2021 р. постановою Верховного Суду по справі № 300/2156/19 [8] було затверджене рішення (яке також дублює Рекомендації МОП № 198) щодо встановлення в Україні факту існування трудових відносин між сторонами через критерії підпорядкованості та залежності, тим самим підтвердивши, що в Україні з 01.01.2016 р. виплати за цивільноправовим договором обкладаються тими ж самими податками і зборами, що й виплати із заробітної
Отже, на даний момент кожна особа, яка реалізує своє конституційне право на працю, стає учасником (стороною) трудових відносин, змістом яких і $\in$ безпосередня трудова діяльність людини. Характерними ознаками трудових відносин вважаються: 1) «жива праця», тобто безпосередня участь людини в процесі праці на підприємстві, установі, організації будь-якої форми власності або у фізичної особи за наймом; 2) включення працівника у трудовий колектив за місцем його роботи; 3) наявність визначеного робочого місця працівника; 4) як правило, підпорядкування працівника внутрішньому трудовому розпорядку.

На думку проф. Г.І. Чанишевої, до ознак трудових відносин «варто віднести такі: 1) об'єктом трудових правовідносин $€$ жива праця, надання в розпорядження роботодавця робочої сили, а їхніми сторонами - найманий працівник і роботодавець; 2) працівник виконує роботу за обумовленою трудовою функцією, тобто за конкретною посадою, спеціальністю, кваліфікацією, а не за конкретно визначений обсяг робіт, як у цивільних правовідносинах; 3) працівник включається до складу трудового колективу підприємства (установи, організації); 4) працівник виконує роботу відповідно до вказівок і під контролем роботодавця з підляганням внутрішньому трудовому розпорядку; 5) робота виконується особисто працівником виключно або головним чином в інтересах роботодавця на визначеному працівникові робочому місці, на якому вимагається його присутність, із

плати за трудовим договором (тобто працівникові, що працює за трудовою угодою, також зараховується страховий стаж відповідно до відрахувань до Пенсійного фонду України; у такому разі, як сказала одна відома в українському суспільстві особа, «яка різниця», за яким договором працювати - трудовим чи цивільно-правовим, якщо роботодавець сплачує за тебе $\in C B ?)$.

Між тим особа вважається працівником, якщо: 1) її призначено (прийнято) на посаду з певними обов'язками, визначено режим роботи і тривалість робочого часу; 2) контролюється, коли, де і як виконується робота; 3) сплачується фіксована погодинна, щотижнева чи місячна заробітна плата; 4) оплачується процес праці, а не ії результат; 5) надаються матеріали та обладнання для виконання роботи; 6) надаються вихідні дні та оплачувані відпустки тощо (за матеріалами вебсайта Державної служби України з питань праці). 
наданням працівнику необхідних для роботи засобів (інструментів, матеріалів, механізмів тощо); 6) на роботодавця покладені обов'язки організувати процес праці та забезпечувати належні, безпечні та здорові умови праці, необхідні для виконання роботи; 7) у трудових правовідносинах регламентується тривалість робочого часу та встановлюються норми праці; 8) працівникові періодично (у встановлені колективним договором або трудовим договором строки) виплачується заробітна плата, яка $€$ єдиним або основним джерелом його доходів, у розмірі не нижче мінімальної заробітної плати; 9) для трудових правовідносин характерний триваючий характер існування, тобто виконання сторонами своїх обов'язків стосовно один одного не припиняє зазначені правовідносини; 10) на працівника поширюються гарантії та пільги, передбачені трудовим законодавством, іншими нормативно-правовими актами, що містять норми трудового права, колективними договорами і колективними угодами (надання щорічної відпустки, вихідних, святкових і неробочих днів, оплата надурочної роботи тощо); 11) у трудових правовідносинах працівник не несе фінансового ризику під час виконання роботи; 12) у трудових правовідносинах роботодавець бере участь у фінансуванні соціального страхування працівника» [9, с. 79-80]. Дана точка зору заслуговує на увагу, але вважаємо, що у зв'язку із внесенням змін до чинного КЗпП України щодо запровадження дистанційної роботи ознаки, перелічені вченою у пунктах 4-7, не зовсім відповідають вимогам статей 29, 60, 60-1, 60-2 Кодексу.

Щодо самозахисту в трудових відносинах: мета самозахисту (будь-де) полягає в тому, щоб усунути порушення своїх прав або перешкод в їх реалізації (і трудові права - не виключення). Як правило, самозахист здійснюється, коли вже має місце порушення трудових прав (або порушення триває), і працівник самостійно вибирає на власний розсуд саме ту форму захисту своїх порушених прав, яку вважає за більш дієву та ефективну. Наразі зауважимо, що чинний КЗпП не пояснює, що таке «само- захист у трудових відносинах», але його розуміння викладене у ч. 6 ст. 55 чинної Конституції України. У такому разі самозахистом у трудових відносинах можна вважати відмову від виконання роботи, яка не передбачена трудовим договором (ст. 31 КЗпП України), а також відмову від роботи, яка $\epsilon$ небезпечною для життя і здоров'я працівника (4. 5 ст. 153 КЗпП України); або проведення переговорів з роботодавцем (самостійно або за допомогою спеціально навченого фахівця, який володіє відповідними методиками 3 організації та ведення переговорів) щодо порушеного права з вимогою усунути це порушення; або звернення по допомогу до КТС чи до суду. Також, на нашу думку, самозахист доречний, якщо йдеться про зміну істотних умов праці (ст. ст. 9, 32 КЗпП України); під час працевлаштування (ст. ст. 22, 25, 26 КЗпП України); якщо мають місце нездорові відносини з роботодавцем (ч. 3 ст. 38 КЗпП України) або можливість припинити роботу після закінчення двотижневого терміну попередження про звільнення за власним бажанням (ч. 1 ст. 38 КЗпП).

3 нашої точки зору, самозахист має розпочинатися тільки після попередження роботодавця (або безпосереднього керівника працівника), й бажано, щоб це попередження було письмовим (інакше поведінка працівника з позиції роботодавця вважатиметься як порушення трудової дисципліни, ст. ст. 139, 140 КЗпП України); застосовувані працівником заходи мають бути адекватними та співвідносними з рівнем порушеного права (тобто не переходити за так звані «червоні лінії»). 3 моменту досягнення мети самозахисту працівник зобов'язаний приступити до роботи (якщо під самозахистом не розглядати остаточне припинення трудових відносин 3 роботодавцем). Те, що працівник не дозволяє себе кривдити, - добре, але маємо проблему на рівному місці: якщо працівник «включає самозахист», то як цей період відображати в Табелі обліку робочого часу (і чи відображати взагалі)?

Як бачимо, самозахистом вважається відмова від виконання роботи, яка або не передбачена в трудовому договорі, або яка завдає (чи може завдати) шкоди 
працівникові. Але можливий й інший варіант самозахисту, умовно ми назвали його «самозахист від звільнення» (небажання втратити роботу), такий собі «хитрий лайфхак» від працівника, який набуває неабиякої популярності: як правило, за два місяці до закінчення строку дії трудового договору (контракту) працівник вчиняє трудове правопорушення, завдаючи своїми діями (чи бездіяльністю) значної шкоди підприємству, установі, організації. Як результат - працівник притягується до матеріальної відповідальності й повинен відшкодувати роботодавцю завдані збитки. Якщо роботодавець звільнить працівника, то він не отримає очікуваної компенсації від працівника. Отже, роботодавець змушений укласти новий строковий трудовий договір (як правило, на один рік) з працівником, і впродовж цього терміну із заробітної плати працівника на користь роботодавця відраховуються певні суми, якими компенсуються завдані збитки (ст. 128 КЗпП України). А далі ситуація повторюється. Як казав ще один відомий класик, «маємо те, що маємо» - роботодавець хоче, але не може звільнити працівника (бо не отримав повної компенсації за завдані збитки), а працівник не хоче припиняти трудові відносини з роботодавцем, бо не впевнений, що зможе знайти собі іншу роботу.

Отже, індивідуальні трудові спори виникають із трудових відносин. Чинне законодавство про працю України розрізняє 2 види індивідуальних трудових спорів: 1) між працівником і роботодавцем у зв'язку із застосуванням умов праці; 2) між працівником і роботодавцем у зв'язку із встановленням або зміною умов праці.

Як ми вже зазначали, чинний КЗпП України лише визначає порядок розгляду індивідуального трудового спору і при цьому не пояснює, що саме вважається індивідуальним трудовим спором. Наприклад, В.М. Дейнека пропонує індивідуальними трудовими спорами вважати «неврегульовані шляхом безпосередніх переговорів, а також за допомогою інших форм захисту, розбіжності між працівником і роботодавцем щодо застосування трудового законодавства, договорів про працю або встановлення чи зміни умов праці, передані на розгляд відповідного юрисдикційного органу (комісії з трудових спорів, суду)» $[10$, с. 76].

3 точки зору розробників пТК № 1658 [11], індивідуальний трудовий спір - це спір між працівником і роботодавцем, що виникає під час здійснення трудових відносин, а в окремих випадках - до їх початку або після їх припинення; предметом даного спору можуть бути питання укладення, зміни, припинення трудового договору, встановлення або зміни умов праці, оплати праці, виконання вимог трудового законодавства, угод, колективного чи трудового договору, інших вимог працівника або роботодавця щодо порушення їхніх прав (ст. 367); стороною індивідуального трудового спору може бути й особа, яка раніше перебувала у трудових відносинах з роботодавцем, а також особа, якій відмовили в укладенні трудового договору (ст. 368).

Розробники проєкту Закону «Про працю» № 2708 [12] пропонують своє бачення цього питання. Зауважимо, що їхнє визначення індивідуального трудового спору збігається з визначенням, що міститься у пТК № 1658, з єдиною різницею, що це - «розбіжності» між працівником і роботодавцем, а не «спір» (4. 1 ст. 84). Предметом спору можуть бути питання укладення, зміни, припинення трудового договору, встановлення або зміни умов праці, оплати праці, виконання вимог трудового договору (4. 2 ст. 84), сторонами індивідуального трудового спору, окрім працівника та роботодавця, $\epsilon$ особа, яка раніше перебувала в трудових відносинах із роботодавцем, та особа, якій відмовили в укладенні трудового договору (4. 3, 4 Ст. 84).

Розробники проєкту Закону № 5555 [13] визначають індивідуальний трудовий спір як розбіжності між працівником і власником або уповноваженим ним органом, що виникають після укладення трудового договору, до його укладення або після його припинення (ч. 1 ст. 221). Предметом зазначеного спору можуть бути питання з укладення, зміни, припинення трудового договору, встановлення або зміни умов праці, оплати праці, виконання вимог законодавства про працю, угод, колективного чи трудового договору та інших 
вимог сторін даного спору щодо порушення їхніх прав (ч. 2 ст. 221) - як бачимо, предмет індивідуального трудового спору в цій редакції такий самий, як і в пТК № 1658. Сторонами спору є: 1) працівник; 2) власник або уповноважений ним орган; 3) фізична особа, яка використовує найману працю; 4) особа, яка раніше перебувала в трудових відносинах; 5) особа, якій відмовили в укладенні трудового договору (ч. 3 ст. 221).

На нашу думку, в разі одночасного прийняття проєктів Законів № 5555, № 5054 (або 5054-1) матиме місце деяка неузгодженість між ними щодо понятійного визначення сторін трудових відносин - «працівник» та «роботодавець» відповідно до проєкту Закону № 5054 (або 5054-1) та «працівник», «власник або уповноважений ним орган» і «фізична особа, яка використовує найману працю» з точки зору проєкта Закону № 5555. Отже, законодавцю спочатку необхідно визначитись (на понятійному рівні) зі сторонами трудових відносин, а потім уже пропонувати своє бачення з вирішення конфліктних ситуацій.

Наразі індивідуальні трудові спори можуть розглядатись комісіями по трудових спорах та районними, районними в місті, міськими чи міськрайонними судами (ч. 1 ст. 221 КЗпП України). Натомість, проєкти Законів № 2708, № 5555 пропонують розглядати такі трудові спори в місцевих та апеляційних судах, а також у Верховному Суді ${ }^{3}$. Але якщо проєкт Закону № 5555 допускає можливість розгляду індивідуального трудового спору комісією з трудових спорів за умови ії створення (4. 2 ст. 222), то проєкт Закону № 2708 в принципі не розглядає сам факт існування КТС. При цьому обидва законопроєкти рекомендують конфліктуючим сторонам скористатись послугами професійних медіаторів.

\footnotetext{
зящо законодавець не виключає розгляд трудового спору Верховним Судом (касаційне провадження), то сама справа (предмет спору) повинна дуже зацікавити Суд, адже наразі справи по трудових спорах віднесені до категорії так званих «малозначних справ». Судові рішення в малозначних справах та у справах з ціною позову, що не перевищує 250 розмірів прожиткового мінімуму для працездатних осіб, не підлягають касаційному оскарженню (п. 2 ч. 3 ст. 389 ЦПК в редакції Закону України № 460-IX від 15.01.2020 р.).
}

Щодо строків у розгляді індивідуальних трудових спорів у КТС та в судовому порядку за чинним КЗпП України і відповідно до проєкту Закону № 5555: для зручності ми їх оформили у вигляді порівняльної таблиці (табл. 1).

Отже, проєктом Закону № 5555 (на відміну від чинного КЗпП України) пояснюється місія КТС, яка полягає у сприянні «вирішенню індивідуального трудового спору шляхом пошуку взаємоприйнятних рішень, усунення порушень прав сторін індивідуального трудового спору та їх примирення» [13, 4. 1 ст. 223]; конфліктна ситуація розглядається на підставі поданої заяви зацікавленою стороною, але не зрозуміло, в які терміни така заява повинна бути подана; акцентується увага на тому, що рішення «приймається за згодою між представниками сторін індивідуального трудового спору, які беруть участь в її засіданні», а в разі «незгоди хоча 6 одного із членів комісії з рішенням, що пропонується до прийняття, воно вважається неприйнятим» [13, 4. 1 ст. 224]. I тут також незрозуміло, які наступні дії повинна вчинити сторона, права якої були порушені: чи повторно звертатись із заявою до КТС, яка вже в оновленому складі буде з'ясовувати, як вирішити конфліктну ситуацію; або ж готуватись до розгляду справи в судовому порядку?

Наступне, що привертає увагу, - пропозиція обмежити строк звернення працівника до суду про стягнення заробітної плати, гарантійних та компенсаційних виплат протягом року з дня, коли він дізнався або повинен був дізнатися про таке порушення. Пояснюється це тим, що «натепер цей строк не обмежений, що створює передумови для зловживання своїм правом недобросовісним позивачам. Поширеними $\epsilon$ випадки, коли особа, зловживаючи своїм правом на звернення до суду через відсутність встановленого строку на таке звернення, навмисно чекає тривалий період часу для того, щоб стягнути з роботодавця велику суму середнього заробітку за час затримки розрахунку» [14]. Тобто законодавець упевнений, що скрізь і всюди процвітає професійне сутяжництво, до якого із задоволенням вдаються ображені роботодавцем працівники. 
Таблиця 1

Строки під час розгляду індивідуальних трудових спорів у КТС

\begin{tabular}{|c|c|}
\hline Вид строку & $\begin{array}{c}\text { Термін (відповідно } \\
\text { до чинного КЗпП України) }\end{array}$ \\
\hline 1 & 2 \\
\hline Строк звернення до КТС & $\begin{array}{l}\text { 1) } 3 \text { місяці з дня, коли працівник } \\
\text { дізнався або повинен був дізна- } \\
\text { тися про порушення свого права } \\
\text { (ч. } 1 \text { ст. 225); } \\
\text { 2) без обмеження будь-яким } \\
\text { строком - у справах про виплату } \\
\text { належної працівникові заробітної } \\
\text { плати (ч. } 1 \text { ст. 225) }\end{array}$ \\
\hline $\begin{array}{l}\text { Строк розгляду } \\
\text { спору в КТС }\end{array}$ & $\begin{array}{l}10 \text { днів із дня подання заяви } \\
\text { (4. } 1 \text { ст. 226) }\end{array}$ \\
\hline
\end{tabular}

Строк вручення копій рішення 3 дні (ч. 3 ст. 227)

КТС працівникові, роботодавцю

Строк для оскарження 10 днів із дня вручення відповідрішення КТС в суді ній особі виписки з протоколу засідання КТС чи його копії (ст. 228)

10 днів із дня вручення сторонам індивідуального трудового спору копії рішення КТС (4. 3 ст. 224)

Строк виконання рішення КТС \begin{tabular}{l|l} 
1) 3 дні після закінчення 10-ден- \\
ного строку, передбаченого для
\end{tabular} ного строку, передбаченого
оскарження рішення (ст. 229); 2) негайно - рішення про понов3 дні після закінчення 10-денного строку, передбаченого для оскарження рішення (4. 3 ст. 224) деного на іншу роботу працівника (4. 7 ст. 235)

Строк для пред'явлення 3 місяці з дати видачі посвідпосвідчення, виданого КТС, чення; у даній ситуації посвіддо органу державної виконав- чення має силу виконавчого чої служби або приватному листа (ч. 4 ст. 230) виконавцю

\section{Термін (відповідно до проєкту Закону № 5555)}

3

Конфліктна ситуація розглядається са підставі поданої до КТС заяви зацітрудового спору (ч. 2 ст. 222)

Порядок розгляду спору визначається колективним договором чи актом власника або уповноваженого ним органу, фізичної особи, яка використовує найману працю, погодженим 3 виборним органом первинної профспілкової організації (ч. 4 ст. 223)

3 дні (ч. 1 ст. 224)

Строки під час розгляду індивідуальних трудових спорів у судовому порядку

\begin{tabular}{l|l|l|l}
\hline Вид строку & Термін (відповідно до чинного Термін (відповідно до проєкту Закону
\end{tabular} КЗпП України, ЦПК України) № 5555)

Строк звернення до суду

1) 10 днів - для оскарження в суді рішення КТС (ст. 228);

3 місяці з дати видачі посвідчення; у даній ситуації посвідчення має силу виконавчого листа (4. 7 ст. 224)

1) 3 місяці з дня, коли фізична особа дізналася або повинна була дізна-

2) 3 місяці з дня, коли працівник дізнався або повинен був дізнатися про порушення свого права (4. 1 ст. 233);

3) 1 місяць із дня вручення копії наказу про звільнення та видачі трудової книжки (ч. 1 ст. 233) - у справах про звільнення; тись про порушення своїх прав (ч. 1 CT. 225);

2) 3 місяці - у справах про звільнення (відлік починається з дня звільнення), 4. 1 ст. 225;

3) для звернення про стягнення належних сум заробітної плати, гарантійних та компенсаційних виплат 4) без обмеження будь-яким стро- 3 роки з дня, коли фізична особа ком - для звернення про стягнення дізналася або повинна була дізнатися належної працівникові заробітної про таке порушення (ч. 2 ст. 225); плати в разі порушення законо- 4) 1 місяць із дня отримання акту про давства про оплату праці (ч. 2 ст. відмову сторін від підписання мирової 233), а також у разі виплати пра- угоди, складеного медіатором (медіацівникові гарантійних та компен- торами), ч. 3 ст. 225;

саційних виплат (ст. 238); ввернення власника мировій угоді як термін виконання або уповноваженого ним органу з відповідного зобов'язання - у разі приводу стягнення з працівника невиконання іншою стороною індивіматеріальної шкоди, заподіяної дуального трудового спору взятих на підприємству, установі, організації себе зобов'язань (ч. 4 ст. 225);

(4. 3 ст. 233);

6) 3 місяці з дня, коли роботодавець 6) 1 рік - у разі звернення до суду дізнався або повинен був дізнатись вищестоящого органу (4. 4 ст. 233) про порушення працівником його прав (4. 5 ст. 225); 


\begin{tabular}{|c|c|c|}
\hline & & Закінчення таблиці 1 \\
\hline 1 & 2 & 3 \\
\hline $\begin{array}{l}\text { Строк звернення до суду } \\
\text { (продовження) }\end{array}$ & & $\begin{array}{l}\text { 7) у разі стягнення з працівника мате- } \\
\text { ріальної шкоди - } 1 \text { рік з дня, коли } \\
\text { роботодавець дізнався або повинен } \\
\text { був дізнатись про порушення своїх } \\
\text { прав (ч. } 5 \text { ст. 225); } \\
\text { 8) } 10 \text { днів - для оскарження рішення } \\
\text { КТС (ч. } 6 \text { ст. 225) }\end{array}$ \\
\hline $\begin{array}{l}\text { Строк підготовки справи до } \\
\text { розгляду }\end{array}$ & $\begin{array}{l}5 \text { днів із дня прийняття заяви (ч. } 1 \\
\text { ст. } 187 \text { ЦПК) }\end{array}$ & Такий самий \\
\hline Строк розгляду справи & $\begin{array}{l}\text { спрощене позовне провадження, } \\
\text { статус «малозначної справи» } \\
\text { (п. } 2 \text { ч. } 4 \text { ст. } 19 \text { ЦПК), не більше } \\
\text { 60-ти днів із дня відкриття про- } \\
\text { вадження у справі (ст. } 275 \text { ЦПК) }\end{array}$ & Такий самий \\
\hline $\begin{array}{l}\text { Строк для апеляційного } \\
\text { оскарження рішення суду }\end{array}$ & $\begin{array}{l}1 \text { місяць із наступного дня після } \\
\text { проголошення рішення (ст. } 354 \\
\text { ЦПК) }\end{array}$ & Такий самий \\
\hline $\begin{array}{l}\text { Строк для касаційного оскар- } \\
\text { ження рішення суду }\end{array}$ & $\begin{array}{l}1 \text { місяць із дня проголошення } \\
\text { рішення суду (ч. } 1 \text { ст. } 390 \text { ЦПК). } \\
\text { Але, увага! Судові рішення в мало- } \\
\text { значних справах та у справах з } \\
\text { ціною позову, що не перевищує } \\
250 \text { розмірів прожиткового міні- } \\
\text { муму для працездатних осіб, не } \\
\text { підлягають касаційному оскар- } \\
\text { женню (п. } 2 \text { ч. } 3 \text { ст. } 389 \text { ЦПК в } \\
\text { редакції Закону України № 460-IX } \\
\text { від 15.01.2020 р.) }\end{array}$ & Так само \\
\hline $\begin{array}{l}\text { Строки виконання рішень } \\
\text { суду }\end{array}$ & $\begin{array}{l}\text { 1) негайно - рішення про понов- } \\
\text { лення на роботі незаконно звіль- } \\
\text { неного або переведеного на іншу } \\
\text { роботу працівника (ч. } 7 \text { ст. 235); } \\
\text { 2) негайно - рішення про виплату } \\
\text { працівникові середнього заро- } \\
\text { бітку за час вимушеного прогулу } \\
\text { або різниці в заробітку за час } \\
\text { виконання роботи, що оплачу- } \\
\text { ється нижче, але не більш як за } \\
\text { один рік (ч. 2, } 7 \text { ст. 235); } \\
\text { 3) негайно -ухвала про виплату } \\
\text { працівникові середнього заро- } \\
\text { бітку або різниці в заробітку } \\
\text { за час вимушеного прогулу у } \\
\text { зв'язку із затримкою виконання } \\
\text { рішення суду (ст. 236); } \\
\text { 4) якщо розгляд справи щодо } \\
\text { поновлення на роботі триває } \\
\text { більше одного року - рішення про } \\
\text { виплату середньго заробітку за } \\
\text { весь час вимушеного прогулу (ч. } 2 \\
\text { ст. 235 кЗпП) }\end{array}$ & $\begin{array}{l}\text { 1) негайно - рішення про понов- } \\
\text { лення незаконно звільненого або } \\
\text { переведеного на іншу роботу пра- } \\
\text { цівника (ч. } 1 \text { ст. 228); } \\
\text { 2) негайно - рішення про виплату } \\
\text { працівникові середнього заробітку } \\
\text { за час вимушеного прогулу або в } \\
\text { різниці заробітку за час виконання } \\
\text { роботи, що оплачується нижче, але } \\
\text { не більш як за один рік (п. 2 ч. } 1 \\
\text { ст. 227); } \\
\text { 3) негайно - ухвала про виплату } \\
\text { працівникові середнього заробітку } \\
\text { або різниці в заробітку за весь час } \\
\text { затримки, невиконання рішення } \\
\text { суду (ч. } 3 \text { ст. 228) } \\
\end{array}$ \\
\hline
\end{tabular}

Щодо застосування медіації під час урегулювання індивідуальних трудових спорів: медіацією у сфері трудових відносин $\epsilon$ «досудова та позасудова процедура врегулювання трудового спору шляхом переговорів сторін трудових відносин за допомогою одного або декількох медіаторів» $[12,4.1$ ст. 86], яка складається з декількох етапів: 1) бажання вирішити конфлікт без суду, 2) консультація та вибір медіатора, 3) укладання угоди про застосу- вання медіації, 4) проведення переговорів, 5) розроблення взаємоприйнятного варіанту вирішення конфліктної ситуації, 6) підписання сторонами мирової угоди, 7) виконання мирової угоди. Завдання медіатора полягає в допомозі опонентам розпочати переговори на нейтральній території та зорієнтувати їх на позитивний результат цих перемовин. У свою чергу від конфліктуючих сторін вимагається почути один одного та знайти компромісний варі- 
ант у вирішенні конфліктної ситуації. Вважаємо, на перспективу роботодавцю доцільно самостійно передбачити медіацію на локальному рівні (наприклад, у колективному договорі), у трудових договорах із працівниками.

Так, ідея законодавця з медіацією непогана, але наразі Верховною Радою України не прийнято жодного із проєктів Законів про медіацію. Тому, на нашу думку, спочатку необхідно легалізувати медіацію на державному рівні, а потім уже пропонувати (чи рекомендувати) скористатись ії послугами. Адже допоки не буде прийнято відповідного нормативного акту 3 цього питання, спеціально навчені фахівці в галузі медіації не можуть називатися «медіаторами», лише «конфліктологи», «переговорники», «практикуючі психологи-консультанти» тощо.

Щодо причин виникнення індивідуальних трудових спорів: конфліктні ситуації можуть виникати через: 1) відмову в працевлаштуванні; 2) поновлення на роботі; 3) неправильне нарахування (або виплату) заробітної плати, невиплату нарахованої заробітної плати, компенсаційних та інших видів виплат; 4) встановлення факту перебування в трудових відносинах; 5) визнання недійсними умов праці за контрактом; 6) розголошення конфіденційної інформації; 7) визнання недійсним трудового договору в частині строку тощо.

«Найтоповішими» порушеннями в трудових відносинах вважаються такі (щодо умов праці та їх оплати) ${ }^{4}: 1$ ) недотримання тривалості робочого часу (ч. 1 ст. 50 КЗпП України) - впродовж тривалого часу (як правило, місяця) працівники працюють без вихідних щоденно по 8 годин, що в тиждень становить 56 відпрацьованих годин (підтверджується Табелем обліку робочого часу); 2) всупереч вимогам ч. 1 ст. 53 КЗпП України роботодавець не скорочує на одну годину тривалість роботи працівникам напередодні святкових і неробочих днів; 3) роботодавець не веде облік надурочних годин, відпрацьованих працівниками, як того вимагає ч. 2 ст. 65 КЗпП України; 4) незабезпечення достовірного обліку виконуваної працівниками

\footnotetext{
${ }^{4}$ Див.: постанова Верховного Суду від 31.01.2019 р. по справі № 809/799/17 [16].
}

роботи (робота в надурочний час не відображається в Табелі обліку робочого часу, а отже, і не здійснюється оплата за її виконання); 5) виконані працівниками понаднормові роботи не оплачуються в подвійному розмірі, як того вимагає ст. 106 КЗпП України; 6) незабезпечення щотижневим безперервним відпочинком працівників, як того вимагає ст. 70 КЗпП України; 7) залучення до роботи у вихідні дні (ст. 71 КЗпП України).

Проаналізувавши судову практику за останні 3 роки, наведемо декілька типових (узагальнених) кейсів з індивідуальних трудових спорів.

Кейс № 1. Чому у випадку, якщо між працівником і роботодавцем досягнуто домовленості про припинення трудових відносин за угодою сторін, і буде виданий відповідний наказ про звільнення працівника, а працівник після цього звернеться до суду з позовом про поновлення на роботі, то роботодавцю в даному разі буде складно довести правомірність звільнення працівника? Відповідь очевидна: був укладений трудовий договір в усній формі.

Кейс № 2. Працівник, з яким було укладено усний трудовий договір, звернувся до суду з позовом про відшкодування моральної та матеріальної шкоди. Підставами задоволення позову він вказав, зокрема, порушення роботодавцем п. 4 ч. 1 ст. 24 КЗпП України, а саме: письмовий трудовий договір необхідно укладати, якщо на цьому наполягає працівник.

Кейс № 3. Чому з працівником, який відмовився укласти договір про повну матеріальну відповідальність, трудовий договір припиняється за п. 1 ст. 40 КЗпП України, незважаючи на те, що при цьому скорочення чисельності чи штату працюючих не відбувається? Тому що в даному випадку відбулась ліквідація робочого місця/посади, яке не передбачало укладання договору про повну матеріальну відповідальність.

Кейс № 4. До суду звернувся громадянин з позовом про відновлення на роботу у зв'язку з незаконним звільненням згідно з п. 4 ст. 40 КЗпП України: для обґрунтування своїх вимог він указав, що був прийнятий на роботу в організацію відповідача на посаду молодшого фахівця із встановленням випробування тривалістю 
в 3 місяці і до закінчення цього терміну був звільнений «без поважних причин». Позивач стверджував, що відповідно до ст. 28 КЗпП України протягом терміну випробування він може бути звільнений тільки за підставою, вказаною в цій статті, тобто за незадовільного результату випробування. Розглянувши матеріали справи, суд ухвалив таке рішення: оскільки в період випробування на працівника розповсюджуються всі норми трудового законодавства (ч. 2 ст. 26 КЗпП України), то громадянин був звільнений адміністрацією на загальних підставах правомірно, і в задоволенні позову відмовив.

Підсумовуючи вищенаведене, можна зробити такі висновки:

1) самозахистом у трудових відносинах, у нашому розумінні, вважається відмова від виконання роботи, яка не передбачена трудовим договором (ст. 31 КЗпП України), а також відмова від роботи, яка $\epsilon$ небезпечною для життя і здоров'я працівника (4. 5 ст. 153 КЗпП України); або проведення переговорів з роботодавцем (самостійно або за допомогою спеціально навченого фахівця, який володіє відповідними методиками з організації та ведення переговорів) щодо порушеного права з вимогою усунути це порушення; або звернення по допомогу до КТС або до суду;

2) «самозахистом від звільнення» вважаємо ситуацію, коли роботодавець хоче, але не може звільнити працівника (бо не отримав повної компенсації за завдані збитки), а працівник не хоче припиняти трудові відносини з роботодавцем, бо не впевнений, що зможе знайти собі іншу роботу;
3) допоки на законодавчому рівні не буде врегульовано медіацію, роботодавцю доцільно самостійно передбачити це на локальному рівні (наприклад, у колективному договорі), у трудових договорах з працівниками;

4) трудовими відносинами (у разі прийняття проєкту Закону № 5054) вважатимуться відносини між працівником і роботодавцем, що передбачають виконання за дорученням, під керівництвом і контролем роботодавця особисто працівником за винагороду визначеної роботодавцем роботи;

5) індивідуальним трудовим спором (у разі прийняття проєкту Закону № 5555) вважатимуться розбіжності між працівником і власником або уповноваженим ним органом, що виникають після укладення трудового договору, до його укладення або після його припинення;

6) наразі судові рішення в малозначних справах (якими, з легкої руки законодавця, вважаються і справи з трудових спорів) та у справах з ціною позову, що не перевищує 250 розмірів прожиткового мінімуму для працездатних осіб, не підлягають касаційному оскарженню (отже, сторона, яка програла справу, втрачає сенс на перегляд судового рішення суду першої та апеляційної інстанції касаційним судом, що у свою чергу порушує право особи на повноцінний судовий захист). Тому якщо законодавець не виключає розгляд справ по трудових спорах Верховним Судом, то, вважаємо, потрібно спочатку позбавити такі справи статусу «малозначних». Інакше така ідея втрачає сенс.

\section{ЛITEPATУРA:}

1. Конституція України від 28.06.1996 р. Відомості Верховної Ради України. 1996. № 30. Ст. 141.

2. Трудове право України : підручник / за заг. ред. М.І. Іншина, В.Л. Костюка. 2-ге вид., стереотип. Київ : Юрінком Інтер ; Буква Закону, 2018. 600 с.

3. Кодекс законів про працю України від 10.12.1971 р. Відомості Верховної Ради України. 1971. (Додаток до № 50). Ст. 375. URL: https://zakon.rada.gov.ua/laws/show/322-08/ ed20210610\#Text

4. Рекомендація МОП про трудове правовідношення № 198 від 31.05.2006 p. URL: https:// zakon.rada.gov.ua/laws/show/993_529\#Text

5. Огляд англійської судової практики: частина 2, рішення ВС Великої Британії (пресреліз Асоціації правників України від 09.04.2021р.). URL: https://uba.ua/ukr/news/8403/

6. Про внесення змін до Кодексу законів про працю України щодо визначення поняття трудових відносин та ознак їх наявності : Проєкт закону України № 5054 від 09.02.2021 р. URL: http://w1.c1.rada.gov.ua/pls/zweb2/webproc4_1?pf3511=71071 
7. Про внесення змін до Кодексу законів про працю України щодо регулювання деяких питань трудових відносин : Проєкт закону України № 5054-1 від 25.02.2021 p. URL: http:// w1.c1.rada.gov.ua/pls/zweb2/webproc4_1?pf3511=71251

8. Постанова Верховного Суду від 02.02.2021 р. по справі № 300/2156/19. URL: https:// reyestr.court.gov.ua/Review/94565710

9. Чанишева Г., Щукін О. Ознаки трудових відносин за актами МОП і законодавством України. Юридичний вісник. 2021/1. C. 77-86. DOI: https://doi.org/10.32837/yuv.v0i1.2083

10. Дейнека В.М. Поняття та види індивідуальних трудових спорів. Вісник ОНУ ім. I.I. Мечникова. Правознавство. 2014. Т. 19. Вип. 3 (24). С. 73-79.

11. Проєкт Трудового кодексу України від 24.07.2017 p. № 1658 . URL: http:// w1.c1.rada.gov.ua/pls/zweb2/webproc4_1?pf3511=53221

12. Про працю : проєкт Закону України від 28.12.2019 р. № 2708.

13. Про внесення змін до Кодексу законів про працю України щодо удосконалення процедури вирішення індивідуальних трудових спорів : проєкт Закону України від 19.05.2021 p. № 5555.

14. Пояснювальна записка до проєкту Закону України «Про внесення змін до Кодексу законів про працю України щодо вдосконалення процедури вирішення індивідуальних трудових спорів» від 19.05.2021 р. № 5555.

15. Цивільний процесуальний кодекс України від 18.03.2004 р. Відомості Верховної Ради України. 2004. № 40-41, 42. Ст. 492.

16. Постанова Верховного Суду від 31.01.2019 р. по справі № 809/799/17. 